\title{
Determinants of entrepreneurship: an examination of entrepreneurial perception of students
}

\author{
Cristina Lidia Maneaa, Elena-Mirela Nichitaa, ${ }^{a}$, and \\ Alina Mihada Irimescua \\ a The Bucharest University of Economic Studies, Romania
}

\begin{abstract}
Research Question: What determinants drive the entrepreneurial intentions of students enrolled in accounting master programs: entrepreneurial competencies, family and friends support or entrepreneurial education? Motivation: The current research purpose is to explore to what extent the entrepreneurship is a feasible al ternative career for students enrolled in accounting master programs and the role of academic education in entrepreneurship in selecting the entrepreneurial career. Generally, entrepreneurs are associated with providers of novel products and/or services, but we consi der the entrepreneurial career in accounting services as feasible as any other career. Idea: The student's interest in entrepreneurial activities remai ns greatly influenced by the entrepreneurial universities policies, making the role of universities crucial. Based on the affirmation that current students will be tomorrow's successful entrepreneurs (Pribeanu and Milutin, 2014), it is essential to increase the impact of entrepreneurial education on the student's life. It is not easy for universities, knowing the changes and chal lenges that they haveto face nowadays (Schulte, 2014), but it is their responsibility and they do have the responsibility to makethe change possible. Data: The data of this paper is collected based on a survey on the student's perception on entrepreneurship and analyses the competences and abilities they gain as result of their bachelor studies and how these perceived competencies and abilities are currently helping or will help them to choose an entrepreneurial career. Tools. The study is based on a questionnai re distributed to master students enrolled in accounting master programs organized by TheBucharest
\end{abstract}

${ }^{1}$ Corresponding author: Department of Accounting and Audit, The Bucharest University of Economic Studies, Piata Romana, no. 6; tel. (+40) 745.972.468; email address: mirela.nichita@cig.ase.ro. 
University of Economic Studies. Theresearch methodology consists of a descriptive analysis and regression analysis. Additionally, the structure of questionnai re allows us to use the Carlsson et al.'s (2012) framework for investigating the entrepreneurship, which is based on two perspectives, namely explorative and exploitative. Findings. The findings allow to state that students are taking into consideration the entrepreneurship career and their decision is positively influenced by family and friends setting and education. The test of the models resulted in adjusted R-squares higher than 0.90 indicating robust support for the regression models. Contribution: Our empirical study investigates three determinants of entrepreneurial skills and, as result of this research, universities, government officials and others interested in stimulating entrepreneurial motivation should consider how their actions affect potential entrepreneurs' enthusiasm Furthermore, this academic paper enhances the Romanian academic literature in the field of entrepreneurship.

K eywords: entrepreneurship, willingness to become an entrepreneur, family support, entrepreneurial skills, entrepreneurial education

\section{J EL codes: I25, M41}

\section{Introduction}

Research in entrepreneurship is to some extent contemporary and rapidly progressing, and is acknowledged in sub-fields within several subjects: economics, management / business administration, sociology, strategy, marketing, finance, economic and cultural anthropology representing a mixture of research practices, perspectives and methods.

The long-time classical economic theory developed by A. Smith based on equilibrium models was challenged by Schumpeter' theory of "creative destruction" (1934) bringing into light the agents who tend to break the equilibrium by introduction innovations, currently, agents are known as entrepreneurs.

The research in evolution of entrepreneurship theory (Carlsson et al., 2012) ascertains that entrepreneurship covers two perspectives: firstly, explorative standpoint of entrepreneurship focusing on the role, characteristics and behaviour of individuals and how they associate to create businesses and, secondly, exploitative standpoint of entrepreneurship which analyse the outcomes of activities and how these outcomes are influenced by socioeconomic environment: institutions, norms, 
finance, economic and social policies. Across the academic literature in entrepreneurship domain, the definition is varying between explorative and exploitative (Acs \& Audretsch, 2003; Carlsson et al., 2012; Casson, 1982; Hebert \& Link, 1989; OECD, 1998; Shane \& Venkataraman, 2000; Stevenson, 2004).

Entrepreneurship can be generally defined as the identification and systematized exploitation of unusual and creative opportunities for value creation and capture, where the intended value outcomes may be commercial, social, institutional, or cultural in nature (I azzolino et al., 2019).

European Reference Framework for key competencies for lifelong learning defines entrepreneurship as: "A sense of initiative and entrepreneurship is the ability to turn ideas into action. It involves creativity, innovation and risk-taking, as well as the ability to plan and to manage projects in order to achieve objectives. The individual is aware of the context of his/her work and is able to seize opportunities that arise. It is the foundation for acqui ring more specific skills and knowl edge needed by those establishing or contributing to social or commercial activity. This should include awareness of ethical values and the promotion of good governance" (European Commission, 2006, 2018)

EU has entitled entrepreneurial skills, encouraging entrepreneurship by fostering the right mind-set and awareness of career opportunities as an entrepreneur, as objectives and methods for European education system (Komarkova, 2015).

The current academic paper is combining both, explorative and exploitative angles acknowledged by Carlsson et al. (2012); the explorative perspective of entrepreneurship is putting into light the individual characteristics and judgements of students enrolled in accounting master programs about entrepreneurship offering an overview concerning the drivers that motivate them to engage into new ventures; in addition, the expl oitative perspective examines the academic curricul a to highlight the receptiveness of university in respect to entrepreneurship themes.

The data of this paper is collected based on a survey on the student's perception on entrepreneurship and analyses the competencies and abilities they gain as result of their bachelor studies and how these perceived competences and abilities are currently helping or will help them to choose an entrepreneurial career.

Entrepreneurship education is crucial for boosting economic growth (Acs, 2006; Carree \& Thurik, 2010; Thurik \& Wennekers, 2004) as it allows to run free the entrepreneurial potential of young people, helping them to develop a critical eyefor entrepreneurial opportunities, skills to prepare assignments, and an ability for taking 
responsibility. Developing these key competencies requires an educational environment that encourages invention and creativity, permitting for taking risk and for making mistakes, which should be valued as a learning opportunity (Moberg, 2014).

Following the Hambrick's (2007) and Marin et al.' s (2015) assertion that structural researchers must balancetheoretical with practical implications, this study addresses the issue on entrepreneurship that we consider to be of great importance for universities in model ling the curricula to develop and enhance the entrepreneurial skills of their students.

This investigation aims to offer an image of the master students' perceptions and comprehension regarding the match between the design of their competencies and skills and the entrepreneurship, as an option for a worthwhile career.

The paper is organized as follows: the literature review section with focus on entrepreneurial skills and role of education in shaping the entrepreneurial proficiencies, then, research methodology displays the information about questionnai re we used to collect information fromstudents; the results section points out the findings, and, finally, the paper concludes with implications for business and academia, limitations and further research challenges.

\section{Literature review}

A cademic literature analysis suggests that entrepreneurial student interest depends on both external and individual factors (Cooper, 2003; Gartner, 1988; Heblich \& Lederer, 2011; Heider, 1958; Iazzol ino et al., 2019; Medinschi, 2014; Moberg, 2014; Neațu \& Imbrișcă, 2015; Shane, 2002; Shaver, 2004).

External factors are the institutions, such as university context, family business experience and socio-economic context. These circumstances can be encouraging to the development of the knowledge required to start a business and to familiarize the student to the entrepreneurship world. Literature shows a clear connection between the student's willingness to undertake a business and the possibility of accessing the knowledge necessary to do this (Bergmann et al., 2018; European Commission, 2015; Fiet, 2001; Filip, 2017; Negoescu, 2013; Pribeanu \& Milutin, 2014).

Internal factors are the student entrepreneurial attitudes and assertiveness. The desire to start a business is being motivated by a personal passion, which can derive from past experiences and personal abilities. All the factors influencethe decision-making process of the student in deciding for an entrepreneurial career (Acs et al. 2009; 
Ceptureanu, 2015; Davidsson \& Honig, 2003; Munteanu, 2015; Nicodim et al., 2016; Venkataraman, 2000).

\subsection{E ntrepreneurial skills}

The hypothesis that entrepreneurs are general ists who are good at a variety of skills, although not necessarily excellent at anyone (Lazear, 2004) is confirmed by Chen and Thomson's (2014) research paper. The perfect entrepreneur is a bal ance between the cognitive intelligence and training of a manager and emotional intelligence of a leader (Minica, 2017).

Entrepreneurial skills combi ne a range of technical, management and personal skills (EC, 2014; Cooney, 2012; OECD, 2014) as follows: technical skills include communication, environment monitoring, problem solving, technology implementation and use, interpersonal, organisational skills; business management skills include planning and goal setting, decision making, human resources management, marketing, finance, accounting, customer relations, quality control, negotiation, business launch, growth management, compliance with regulations skills, and, respectively, personal entrepreneurial skills that include self-control and discipline, risk management, innovation, persistence, leadership, change management, network building, and strategic thinking.

The outstanding qualities of an entrepreneur are the predilection to take risks (Bădulescu 2015; Călin-Costin, 2013; Ceptureanu 2015; Cișmariu (Zepa), 2014; Ghicajanu, 2015; Kuip \& Verheul; 2003; Medinschi, 2014; Neațu \& Imbrișcă, 2015), the characteristic of high level of optimism(Hmieleski \& Baron, 2009; Neatu \& Imbrisca, 2015), and "alertness" (Demsetz, 2008; Gaglio, 1997; Gaglio \& Kat, 2001; Kirzner, 2009; Manne, 2014; Tang et al., 2012). Some researchers are disagreeing on risk taking feature and state the opposite: the risk aversion attitude encourages individuals to invest in balanced skill profiles, making them more likely to becomeentrepreneurs (Hsieh, 2016). Furthermore, Ceptureanu (2015), Davidsson and Honig (2003), Munteanu (2015) and Nicodim et al. (2016) have shown that social skills, as the ability to take advantages from social connections, networks, are central for becoming an entrepreneur as well as for the success rate of making it through the start-up phase.

Whether a person is an employee or an entrepreneur all that matters is to educate his/her flexibility to meet the challenges, recognize opportunities and step back in time from businesses that have lost their marketplace (Medinschi, 2014). Entrepreneurship is a way of thinking, then a planned behaviour, and finally, an economic activity (Galea, 2017). 
Entrepreneurship competencies combine creativity, a sense of initiative, problemsolving, the ability to manage financial and non-financial resources and technological knowledge. These competencies enable entrepreneurs and entrepreneurial employees to motivate and adapt to economic changes. Entrepreneurial skills and abilities can be developed through entrepreneurship education and trainings that focus on promoting an entrepreneurial mindset and behaviours. (OECD, 2018).

\subsection{The role of education in entrepreneurship}

Although there is an increased appreciation for and acknowledgment of the role played by new and small businesses in the economy (Kelley et al., 2010) and entrepreneurship academic education has begun to knowledge the attention of policy-makers and researchers, there remain many unanswered questions about how individual and social factors shape the decisions of academics to engage in entrepreneurial activities. The first course in entrepreneurship was offered at the Harvard Business School in 1947. Since then, many universities included entrepreneurship subjects into their curricula; moreover, studying entrepreneurship has been suggested to directly conceptualize the relationship between entrepreneurship, labour markets and career options (Burton et al., 2016).

Understanding the dynamics shaping the development of entrepreneurial competencies advances theoretically significant questions as to how entrepreneurs gain competencies and about the extent to which entrepreneurial competencies are the result of individual or contextual factors (Carlsson et al., 2012; Iazzolino et al., 2019; Rasmussen et al., 2014; Rasmussen et al., 2015). Many studies focused their research on the influence that education could have on the aspects and aspirations of young people, while few empirical studies have examined the entrepreneurial predisposition of university students as a source of future entrepreneurs (Wang and Wong, 2004). The goal of entrepreneurship education is to give people the knowledge, skills and attitudes to act in an entrepreneurial way (Moberg, 2014).

Currently, theteaching of entrepreneurship is not yet sufficiently integrated in higher education institutions' curricula (Wang and Wong, 2004). A vailable data show that most entrepreneurship courses are offered in business and economic studies (European Commission, 2008). However, European Commission (2008) is questioning if business schools are the most appropriate places to teach entrepreneurship, since innovative and worthwhile business ideas are more likely to arise from technical, scientific and creativestudies. 
Entrepreneurial education is the main factor in entrepreneurship (Negoescu, 2013) and its aim is to give students the attitudes, knowledge and skills to act in an entrepreneurial manner (Tsakiridou \& Stergiou, 2014), promoting creativity and innovation (Medar, 2015). The knowledge obtained by students is used at workplace (Stanciu \& Tinca, 2017) and, consequently universities should encourage subjects with future-oriented, positive and proactive information, tremendously valuable to entrepreneurs on daily undertakings.

Teaching entrepreneurship is a necessity (Filip, 2017), but this would not limit the difficulties that entrepreneurs faces, but sometimes will even increase them according to Avram and Sabou (2016), who stated that the entrepreneur with a high level of education will permanently search to develop the business, facing new difficulties that need to be solved.

Thestudent's interest on entrepreneurial activities remains greatly influenced by the entrepreneurial universities policies, making the role of universities crucial. Knowing that the present students will be the tomorrows successful entrepreneurs (Pribeanu \& Milutin, 2014), it is essential to increase the impact of entrepreneurial education on the student's life. It is not easy for universities, knowing the changes and challenges that they have to face nowadays (Schulte, 2014), but it is their responsibility and they do have the means to make the change possible. There are a lot of solutions that universities might use to stimulate the spirit of future entrepreneurs.

On one hand, they might ensure the development of students' entrepreneurial specific competences within university by organizing conferences, contests on entrepreneurial topics, valuing the best idea plan, butmoreimportant, by the teaching techniques used in the education process. It is well known that the more diverse the teaching and learning methods used, the broader the learning process is. Therefore, combining the face-to-face interaction teaching methods with the information and communication technologies, and putting the students in a central position will lead to greater efficiency. Many studies (Ceptureanu, 2016; European Commission, 2015; Roșca \& Șipoș-Gug, 2015) demonstrated that student-centred education is stimulating the entrepreneurial spirit of students. Indeed, the learning-by-doing pedagogical approach has positive influence on both, learning experience and development of entrepreneurial skills. Through creativity-based learning, challengebased learning, discovery-based learning (Pavlov, 2014), and business simulation games (Ploae, 2014), the students will experience confidence, will be able to make decisions in uncertainty situations, manage the risk better, find best solutions in a record time and overcome difficulties. Therefore, there is the need for business schools to rethink the use of teaching content and methods rel ated to the development 
and improvement of potential innovative thinking, responsible entrepreneurs (Amundam, 2019)

On the other hand, universities might act by building national and international partnershi ps between uni versities and economic agents (Diaconu \& Duțu, 2016). The connection to the outside world is established by protocols with the training companies, as their role is well known in the entrepreneurial education (Isac, 2017), and by inviting business professionals or entrepreneurs to share their experience and to be perceived as models that might be followed.

There are also the students' organizations that are playing an important role in shaping the entrepreneurial competencies of students through the organization, planning and coordination of complex and diverse activities (Zamcu, 2013). Furthermore, there are universities that are relying on the activity of students' associations to promote social change (Cantaragiu et al., 2014). Along with these students' organizations, Alumni involvement is often useful in motivating students (European Commission, 2015).

\section{R esearch methodology}

The current research aims to investigate the ability to become an entrepreneur, the impact of environment - family and friends support, the willingness to become an entrepreneur and the influence of education on students' attitude in regard with entrepreneurship. As other similar studies (European Commission, 2013; European Social Entrepreneurship and Innovative Studies Institute, 2015; Eryanto \& Swaramarinda, 2018; Fini et al., 2016; Kerr, 2017; OECD, 2007; VOY AGE, 2016), the authors conducted a survey to identify if essential behavioral characteristics for a career in entrepreneurship are encapsulated in master program students' personality and also to motivate university to improve curricula to enhance the entrepreneurship actions.

Thestudents' perception questionnaire (Eryanto \& Swaramarinda, 2018; Peterson et al., 2000; van der Scheer, 2018) comprises three parts: the first 20 questions addressing four main topics: ability to become an entrepreneur, environmental background where students developed their personality, willingness to become an entrepreneur, and the influence of education in the entrepreneurial decision making process; the next five requests collect data about age, gender, work experience, high school profile and bachel or degree; the questionnaire closes with open question, as comments. The construction of questionnai real lows us to apply the Carlsson et al.'s (2012) framework for investigating the entrepreneurship, which is based on two perspectives, namely explorative perspective- personality of entrepreneurs, and 
exploitative perspective - external factors influencing the entrepreneurship career decision.

The survey uses Likert scale (Bertram, 2016; Likert, 1932), from 1 (strongly disagree) to 5 (strongly agree), to assess participants' level of agreement with our proposed statements.

\subsection{Data description}

The data of the research are collected by conducting a survey with $1^{\text {st }}$ and $2^{\text {nd }}$ year students from master programs organized by Accounting and Management Information Systems Faculty from The Bucharest University of Economic Studies, Romania(Accounting, Control and Expertise, Accounting and Taxation of Economic Entities and Financial Analysis and Evaluation); the data were collected by direct distribution of questionnaire at the beginning of the second semester of 2018-2019 academic year and at the beginning of the first semester of 2019-2020 academic year. The first data set consists of 161 questionnaires, from which 157 were accepted as valid, representing a success rate of $97.5 \%$, while the second data set comprises 68 questionnai res with 65 stated as valid (96\%).

Secondary data used in the paper, regarding entrepreneurship, are extracted from curricula of bachelor and master's degree programs organized by The Bucharest University of Economic Studies, Romania.

\subsection{M ethod of analysis}

This paper uses descriptive statistical indicators such as the media, median, sample variance and the coefficient of variation in order to analyse the students' attitude toward their ability as entrepreneurs, impact of environmental background, willingness to become an entrepreneur, and the role of academic education in entrepreneurship decision making process.

Additionally, two regression models are used to test the hypotheses:

H1 Entrepreneurial skills are influenced by education, and

$\mathrm{H} 2$ Willingness to become an entrepreneur is influenced by education and family support

\subsection{Broad view on respondents' profile}

Most of the respondents of our survey are female (over 75\%); the distribution in terms of high school graduated highlights that more than $50 \%$ of the master students have an economic background. Most of the students (more than $71 \%$ ) enrolled in 
Determinants of entrepreneurship: an examination of entrepreneurial perception of students

Accounting master programs have a bachelor's degree in accounting, as shown in table 1.

Table 1. C haracteristics of respondents - master program graduated

\begin{tabular}{lcccc}
\hline \multicolumn{1}{c}{ Bachelor's degree } & $\begin{array}{c}\text { Number of } \\
\text { graduates } \\
\text { for } \\
\text { Data set 1 }\end{array}$ & $\begin{array}{c}\text { Number of } \\
\text { graduates } \\
\text { for } \\
\text { Data set 2 }\end{array}$ & $\%$ \\
\hline $\begin{array}{l}\text { Accounting and Management Information } \\
\text { Systems }\end{array}$ & 111 & $71.15 \%$ & 53 & $81.54 \%$ \\
$\begin{array}{l}\text { Management } \\
\text { Financeand Banking }\end{array}$ & 9 & $5.77 \%$ & 2 & $3.07 \%$ \\
$\begin{array}{l}\text { Theoretical and Applied Economics } \\
\text { Management and Public Administration }\end{array}$ & 4 & $3.85 \%$ & - & - \\
$\begin{array}{l}\text { International Economic Relations } \\
\text { Business and Tourism }\end{array}$ & 3 & $1.56 \%$ & - & - \\
& 3 & $1.92 \%$ & - & - \\
Marketing & 2 & $1.92 \%$ & - & - \\
$\begin{array}{l}\text { Business Administration (in foreign } \\
\text { languages) }\end{array}$ & 2 & $1.28 \%$ & 1 & $1.53 \%$ \\
$\begin{array}{l}\text { Public Administrating - Human resources } \\
\text { Agrifood and environmental economics }\end{array}$ & 1 & $0.64 \%$ & - & - \\
$\begin{array}{l}\text { Faculty formTheUni versity of Economic } \\
\text { Studies, but not declared }\end{array}$ & 1 & $0.64 \%$ & - & - \\
$\begin{array}{l}\text { Other faculty, external of The University } \\
\text { of Economic Studies }\end{array}$ & 4 & $2.56 \%$ & 1 & $1.53 \%$ \\
\hline
\end{tabular}

Our respondents are predominantly young people with age between 19 and 25 years (87.82\%) as shown in table 2.

Table 2. C haracteristics of respondents - age

\begin{tabular}{lcc}
\hline Age & Data set 1 & Data set 2 \\
\hline Y ounger than 25 years & $87.82 \%$ & $89.23 \%$ \\
Age between 26 years and 35 years & $8.97 \%$ & $9.23 \%$ \\
Older than 35 years & $3.21 \%$ & $1.54 \%$ \\
\hline
\end{tabular}

Since the respondents are very young, the work experience is customarily less than 1 year as shown in table 3 .

Table 3. Characteristics of respondents - work experience

\begin{tabular}{lcc}
\hline Work experience (in years) & Data set 1 & Data set 2 \\
\hline Less than 1 year & $58.83 \%$ & $44.62 \%$ \\
Between 1 year and 3 years & $35.89 \%$ & $44.62 \%$ \\
Between 3 years and 5 years & $1.92 \%$ & $9.23 \%$ \\
More than 5 years & $3.84 \%$ & $1.54 \%$ \\
\hline
\end{tabular}




\section{Analysis and results}

\subsection{A bility to become an entrepreneur}

Thefirst part of the questionnai re included questions (Q1 to Q6) that were addressed to observethestudents' perception on owning entrepreneurial competencies, such as risk taking, creativity, self-confidence, independence, hardworking intentions, adapting to changes. These characteristics discuss the explorative perspective of Carlsson et al.'s (2012) framework. Entrepreneurs are risk takers, they have the courage to sacrifices empl oyment benefits, to fed independent, to be their own boss. They are creative and self-confident; they seek opportunities to make benefits and overcome chall lenges and difficulties that inevitably affect all entrepreneurs at some point in their careers. Entrepreneurs work hard, they invest not only money, but time and effort and succeed to adapt to change, make quick decisions. The results show that 31\% from the partici pants have great skills for becoming entrepreneurs, as they accumulated more than 24 points from the total of 30 points on Likert scale.

\subsection{Family and friends support}

An entrepreneur needs family support, from money to encouragements, positive support, understanding in periods of stress, so that he can concentrate on the business. Scott and Twomey (1998) showed that students whose parents owned a business demonstrated higher preference for an entrepreneurial career than a simple employee position. The descriptive analysis from Table 4 shows that almost $76 \%$ from the partici pants declared that they havefamily support to startup their business (Q7), being consistent with Scott and Twomey' s (1998) findings. Parents support is easy to obtain, but wife/husband and children understanding is hard to achieve because they have to accept that an entrepreneur spend a lot of time away from the family.

On the other hand, family might provide inspiration and knowledge about managing a business especially when a parent runs his/her own business. This is al so available for friends. A parent or a friend that is his own manager turn into a model easy to follow. The descriptive analysis shows that 38\% of the students have a member of the family running his own business (Q8) and almost $27 \%$ of them have friends involved in entrepreneurship (Q9). 
Determinants of entrepreneurship: an examination of entrepreneurial perception of students

Table 4. Descriptive statistics on family and friends support

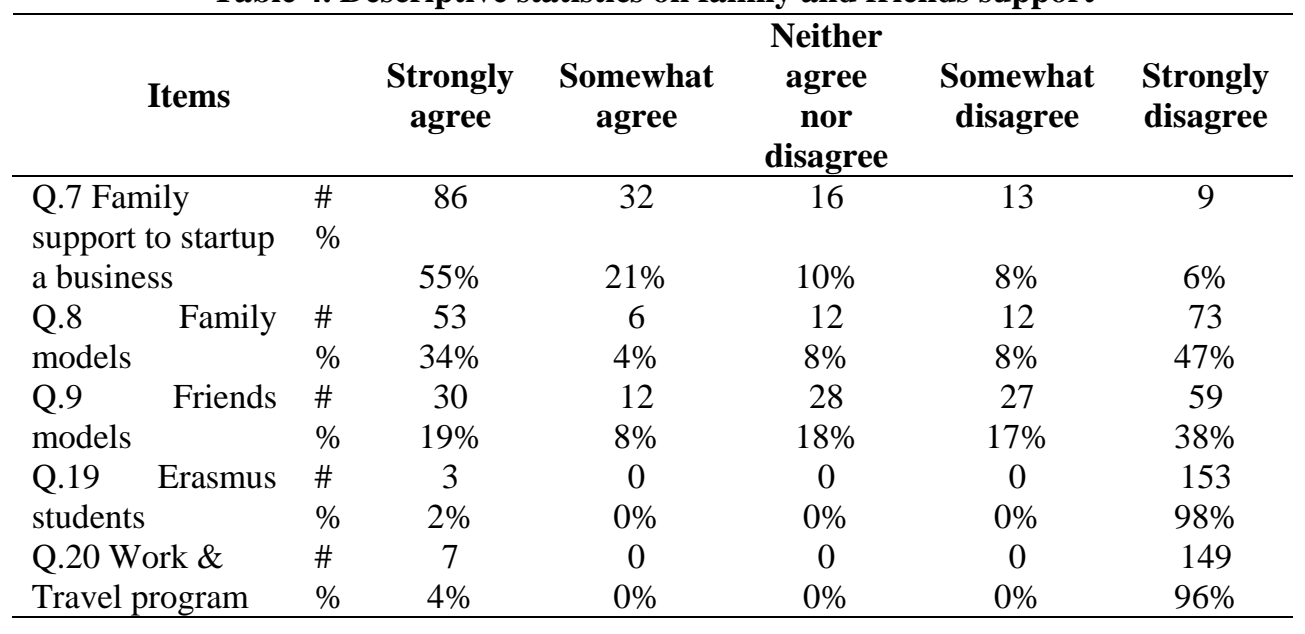

The partici pants were al so asked whether they traveled as Erasmus students (Q 19) or as part of work and travel programs (Q20), in order to investigate if they had the opportunity to connect to other cultures, where young people wish to achieve financial success through entrepreneurship. The survey suggested that an insignificant number of students were part of such programs.

\subsection{Willingness to become an entrepreneur}

Although $84 \%$ from the responds are empl oyees and are enjoying the benefits of a stable career (Q11), almost 60\% expressed the desire to startup their own business (Q10), sacrificing employment benefits as shown in table 5 .

Table 5. Descriptive statistics on willingness to become an entrepreneur

\begin{tabular}{lcccccc}
\hline \multicolumn{1}{c}{ Items } & & $\begin{array}{c}\text { Strongly } \\
\text { agree }\end{array}$ & $\begin{array}{c}\text { Somewhat } \\
\text { agree }\end{array}$ & $\begin{array}{c}\text { Neither } \\
\text { agree nor } \\
\text { disagree }\end{array}$ & $\begin{array}{c}\text { Somewhat } \\
\text { disagree }\end{array}$ & $\begin{array}{c}\text { Strongly } \\
\text { disagree }\end{array}$ \\
\hline Q.10 Willingness to \# & 57 & 36 & 38 & 11 & 14 \\
startup own business & $\%$ & $37 \%$ & $23 \%$ & $24 \%$ & $7 \%$ & $9 \%$ \\
Q.11 Being employee & $\#$ & 122 & 10 & 9 & 3 & 12 \\
& $\%$ & $78 \%$ & $6 \%$ & $6 \%$ & $2 \%$ & $8 \%$ \\
\hline
\end{tabular}

They are willing to risk their regular paycheck for own success in running a business venture. This is consistent with the findings of Tecău (2016) and Bădulescu (2015) who studied the students' perception on embracing a future entrepreneurial career, but al so with Roșca and Șipoș-Gug (2015) who investigated thestudents' inclination towards entrepreneurship. 


\subsection{The influence of education in entrepreneurship decision making process}

Entrepreneurial education is the activity of teaching and learning about entrepreneurship that involve development knowledge, skills, attitude and personal qual ities appropriate to the age and devel opment of the pupils or students ( Lin et al ., 2008).

Education institutions play an important role in shaping the students' interest for entrepreneurship through the implication of professors to promote entrepreneurship and through organizing conferences or contests for students.

Table 6. Descriptive statistics on students' interest on entrepreneurship issue

\begin{tabular}{lcccccc}
\hline \multicolumn{1}{c}{ Items } & & $\begin{array}{c}\text { Strongly } \\
\text { agree }\end{array}$ & $\begin{array}{c}\text { Somewhat } \\
\text { agree }\end{array}$ & $\begin{array}{c}\text { Neither } \\
\text { agree nor } \\
\text { disagree }\end{array}$ & $\begin{array}{c}\text { Somewhat } \\
\text { disagree }\end{array}$ & $\begin{array}{c}\text { Strongly } \\
\text { disagree }\end{array}$ \\
\hline $\begin{array}{l}\text { Q.14 Participating to } \\
\text { entrepreneurship }\end{array}$ & $\%$ & 16 & 9 & 22 & 21 & 88 \\
conferences & $10 \%$ & $6 \%$ & $14 \%$ & $13 \%$ & $56 \%$ \\
Q.15Interest for more & $\#$ & 73 & 47 & 31 & 3 & 2 \\
discussions based on & $\%$ & $47 \%$ & $30 \%$ & $20 \%$ & $2 \%$ & $1 \%$ \\
entrepreneurship & & 11 & 20 & 22 & 36 & 67 \\
Q.17 Participating to & $\#$ & 11 & $13 \%$ & $14 \%$ & $23 \%$ & $43 \%$ \\
entrepreneurial contests $\%$ & $7 \%$ & $13 \%$ & & & & \\
\hline
\end{tabular}

The descriptive analysis from table 6 reveal ed that students have participated to conferences (Q14) and contests (Q17) in a low proportion, $16 \%$ and $20 \%$ respectively, but they have expressed their interest for more discussions based on entrepreneurship (Q15) in a greater proportion, $77 \%$. This huge discrepancy may be explained by the student's convenience they are interested in more information about entrepreneurial issue, but they arenot willing to spend extratime. Accordingly, the solution is to discuss additional entrepreneurial aspects in courses and seminars, more than in conferences. The increased interest in entrepreneurship information is consistent with the results of the research conducted by Sumedrea (2017) according to which students expressed an increased interest in participating in future meetings related to entrepreneurship, consequently, universities have implemented measures to improve their entrepreneurial climate with theai m of fostering the entrepreneurial tendency of students and researchers (Rasmussen \& Borch, 2010). Institution of higher education can encourage academics and students to look beyond classrooms offering workshops and internships as instruments to bridgetheoretical and practical knowledge (Albu et al., 2016) and courses in entrepreneurship (Boh et al., 2016). 
Determinants of entrepreneurship: an examination of entrepreneurial perception of students

\section{Correlations}

For further correl ation the data are tested for homogeneity. Table 7 summarizes the indicators and the coefficient of homogeneity is bel ow the threshold of 35\%, in most of the cases.

Table 7. Descriptive statistical indicators

\begin{tabular}{lccc}
\hline \multicolumn{1}{c}{ Statements on } & M ean & Standard deviation & $\begin{array}{c}\text { Coefficient of } \\
\text { homogeneity } \\
(\%)\end{array}$ \\
\hline $\begin{array}{l}\text { Willingness to start-up own business } \\
\text { Q10 }\end{array}$ & 3.711 & 1.275 & 34.36 \\
$\begin{array}{l}\text { Entrepreneurial skills Q 1-6 } \\
\begin{array}{l}\text { Family support to start-up own } \\
\text { business Q7 }\end{array}\end{array}$ & 3.568 & 0.602 & 16.88 \\
$\begin{array}{l}\text { Entrepreneurship education in } \\
\text { university Q12,13,16 }\end{array}$ & 4.109 & 1.226 & 29.85 \\
\hline
\end{tabular}

Two hypotheses are tested to assess the relation between education, entrepreneurial skills, willingness to become an entrepreneur and family support.

Correlating question 10 responses and those related to entrepreneurial skills, it results in a problematic fact: the number of students who want to run their own businesses exceeded the number of students who have the necessary skills in entrepreneurship, meaning that they succeed to startup their business but most probably they will fail to develop and manage the business venture. The students perceive entrepreneurship as a possi ble career option, they want to take the first step, but they should be hel ped to improvetheir skills in order to succeed as entrepreneurs.

Accordingly, the entrepreneurial skills are influenced by education - hypothesis $\mathrm{H}_{1}$, that will be tested with a regression model. For education there were summarized together multiple Likert items related to discussions on entrepreneurships (Q12), encouragements for becoming an entrepreneur (Q13) and invitations of business professional s or entrepreneurs (Q16). Running the single variable regression model, the equation is:

$E S=\alpha+\beta \times E D$

Where

ES = entrepreneurial skills

$\mathrm{ED}=$ education 
The hypothesis was tested for the both sets of partici pants (2018-2019 academic year and 2019-2020 academic year). The coefficients of the regression equation are statistically significant ( $P$-value $\leq 0.05$ ). The intensity of the relationship between the two variables of the model used is measured by a multiple correlation ratio equal to 0.98 for the both sets of data; there is a di rect rel ationship between variables, of high intensity. Theindependent variable explains $96 \%$ of variation in skills devel opment, the difference of $4 \%$ representing the influence of other factors. The mode that captures the relation between the two variables is valid, with a confidence level of 0.95 (Significance $\mathrm{F} \leq 0.05$ ).

The main conclusion of the regression model is that education is influencing in a significant way (by 96\%) the development of the entrepreneurial skills and this explains why there are significant differences in terms of entrepreneurial skills for students foll owing technical and economic studies (Botezat \& Borza, 2016). It must be noticed that the results are very similar for the both sets of data from different academic years. The results are consistent with the view of Nikoloski et al. (2014) who stated that higher education promote students' entrepreneurial potential in the south-eastern European countries.

To test the hypothesis $\mathrm{H}_{2}$ - The willingness to become an entrepreneur is influenced by education and family support, a regression model is used with two independent variables. The regression model is the following equation:

$W E=\alpha+\beta_{1} \times E D+\beta_{2} \times F F$

Where

WE $=$ willingness to become an entrepreneur

$\mathrm{ED}=$ education

FF $=$ family support

As P-value $\leq 0.05$, the coefficients of regression are statistically significant.

The relationship between the dependent variable and the two independent variables is direct The model is valid with a confidence level of 0.95. The willingness to become an entrepreneur is influenced by education and family support in a significant way (by 93\%). Once again, the results for the 2018-2019 academic year partici pants are very consistent with thosefor 2019-2020 academic year partici pants.

The coefficients of regression models are summarized in Table 8. 
Determinants of entrepreneurship: an examination of entrepreneurial perception of students

Table 8. Parameters of regression models

\begin{tabular}{|c|c|c|c|c|}
\hline & \multicolumn{2}{|c|}{ H1 } & \multicolumn{2}{|c|}{ H2 } \\
\hline Hypotheses & Data set 1 & Data set 2 & Data set 1 & Data set 2 \\
\hline $\begin{array}{l}\text { Coefficient of } \\
\text { determination }\end{array}$ & 0.963 & 0.974 & 0.925 & 0.928 \\
\hline correlation & 0.981 & 0,987 & 0.962 & 0.963 \\
\hline $\begin{array}{l}\text { Fisher Test } \\
\text { Regression } \\
\text { coefficients }\end{array}$ & $4,105.42$ & 2,379.83 & 954.41 & 403.98 \\
\hline $\begin{array}{l}\text { Intercept } \\
\text { Coefficient of }\end{array}$ & 1.80 & 1.66 & -0.31 & -0.38 \\
\hline $\begin{array}{l}\text { regression } 1 \\
\text { Coefficient of }\end{array}$ & 0.54 & 0.61 & 0.48 & 0.41 \\
\hline regression 2 & - & - & 0.62 & 0.70 \\
\hline
\end{tabular}

The val idation of the second hypothesis should belinked to the fact that most of the participants have not studied any entrepreneurship discipline during faculty or master. The analysis of curricula of master programs organized by Accounting and Management Information Systems reveals a lack of disciplines regarding entrepreneurship, even though, the curricula of other faculties comprises a small number of disciplines on entrepreneurship (Table 9). Similar results are found by Pitulice and Manea (2015) when anal yses the entrepreneurial spirit in universities.

Table 9. Subjects on entrepreneurship

\begin{tabular}{lcc}
\hline \multicolumn{1}{c}{ Faculty* } & \multicolumn{2}{c}{ Number of subjects } \\
& Bachelor's degree M aster's degree \\
\hline Agrifood and environmental economics & 2 & 1 \\
Business Administration (in foreign languages) & 2 & 5 \\
Business and Tourism & 1 & 1 \\
Cybernetics, Statistics and Informatics & 3 & 0 \\
Finance and Banking & 1 & 0 \\
International Economic Relations & 2 & 1 \\
Management & 0 & 3 \\
Management and Public Administration & 2 & 0 \\
Marketing & 1 & 0 \\
Theoretical and Applied Economics & 2 & 5 \\
\hline
\end{tabular}

* in al phabetical order

However, the professors have filled this gap by addressing issues related to entrepreneurship in courses or seminars, by encouraging students to become entrepreneurs and by inviting professionals to their activities. 
The above data highlights the unsatisfactory subjects employed in academic curricula, but the same concern exists in other developing countries due to structural, cultural, political and educational difficulties (Toktamysov et al., 2019)

\section{Conclusion}

The entrepreneurial activity is influenced by socioeconomic environment and result in economic growth and human welfare.

The study is based on a students' perception questionnaire distributed to students enrolled in accounting master programs organized by The Bucharest University of Economic Studies during 2018-2020.

The core of this investigation focusses on hypotheses which proves that the entrepreneurial skills are influenced by the education and the willingness to become an entrepreneur is influenced by the education and family support This means that if a master graduate wants to begin his/her own business in near future, he/she would definitely be able to achieve that. No matter there is a social pressure or family obstacles, his/her attitude will have an influence on his/her action. Our findings support the previous studies carried out in this research area (A wan \& A hmad, 2017; Ozaralli \& Rivenburgh, 2016; Peng et al., 2012). Thesi milar resul ts obtained for the both sets of participants from the two different academic years show the val idity of our models.

The current research paper uses the Carlsson et al.'s (2012) framework for examining the entrepreneurship, which is based on two perspectives, namely explorative and exploitative. The explorative perspective is referring to analysis of characteristics of entrepreneurs' personality, for instance, creativity, risk taking attitude, bravery; the expl oitive perspectiveanal yses the support of family and friend as a determinant of choosing an entrepreneurial career, accompanied by examination of academia's syllabuses discussing to entrepreneurship. We identified that more than $1 / 3$ of our responders possess abilities starting their own business and they are not afraid of failure.

Other studies have observed that male students have stronger entrepreneurship aspi rations than females (Wang \& Wong, 2004; Bergmann et al., 2018) which are contradicting our findings where, the sample dominated by female master students conducts to the outcome that both, femal e and male students are willing to engage in entrepreneurial activities.

In our study, we revealed that entrepreneurial education is influencing the willingness of master students in becoming self-employed. This is consistent with 
Kumar etal. (2012) results but, in thesametime, is in opposition with theOosterbeek et al. (2010) findings, as they showed that the entrepreneurial education given by the education institution does not have impact to students' motivation, and intention to become an entrepreneur.

Generally, entrepreneurial education aims to increase awareness in respect of entrepreneurship as a career choice (A rasti et al., 2012).

Entrepreneurial competencies are defined as higher-level, improvablecharacteristics entailing personality traits, skills, and knowledge that bring about the ability to accomplish something through the use of resources (Rasmussen et al., 2011).

Together with findings, our investigation discloses that students are motivated and have a high willingness to become entrepreneur, and their family and friends are supportive in this journey; these results are consistent with Kumar et al.'s (2013) paper.

The limits of research refer to: firstly, the surveys al most al ways carry the risk of sel ection bias. It is possi ble that students may avoid extreme response and may agree with some statements in order to please the experimenter. The survey revels lack of reproducibility and, in many cases is difficult to demonstrate the validity, especially when weanal yse human behaviours (Bertram, 2016). Self-reported data carry certain risks of misperception and confusions; in this case, may be related to the ways in which students perceive the questions and how assess the value reported (strongly agree vs strongly disagree); secondly, the research has only focused on some of master programmes organized by Accounting and Management Information Systems during academic year 2018-2019.

A critic in respect to research methodology based on questionnaire is that the findings cannot be extended to wider populations with the same degree of certainty that quantitative anal yses can (Atieno, 2009).

Entrepreneurship is a combination of mind-sets, knowledge and skills, and higher education should set up a strategy and an action plan for teaching and researching in entrepreneurship embedding practice-based activities, and strengthen relationships with successful entrepreneurs, Alumni of universities, to enhance all above mentioned dimensions.

We recommend to The Bucharest University of Economic Studies to step forward in adjusting their curricul a with more entrepreneurial theme disciplines to contribute in a greater manner in shaping and enlightening the entrepreneurial skills and competences of students; all the more, the OECD (2015) ascertained an increase in number of new ventures created by students and European Commission' studies 
acknowledged entrepreneurial initiative as a key competence for long-life wisdom (Komarkova, 2015).

The future research will attempt to distribute the questionnaire to the students that are enrolled in all master programmes organized by The Bucharest University of Economic Studies and to continue with next cohorts in order to devel op a consistent and reliable data base for future robust researches in entrepreneurial field.

Entrepreneurship is fascinating, in different forms and for different purposes: for the young students and graduates represents a future career opportunity; for higher education institutions is a drive to adjust the academic curricula to the new generations' expectations; for the economy is a key for growth and long-term development (Bădulescu, 2015).

Our paper contributes to this growing academic literature by consi dering the aspects influencing the entrepreneurial decision among masters' students and to start a more coherent conversation about the relationship between entrepreneurship degree curricula and courses hosted by other disciplines within the framework of crossdisciplinary programs. Focusing on the choices and reasoning of young entrepreneurs allows for an in-depth understanding of the relationship between education and practice (Bar-Lev et al., 2019). Additionally, the use of Carlsson et al.'s (2012) framework contributes to organize the paper in a structured manner empowering examination of the personal ity of entrepreneurs and, as well theexternal environment represented by family, friends and university as a provider of knowledge to start a business.

\section{R eferences}

Acs, Z.J. (2016) „How Is Entrepreneurship Good for Economic Growth?", Innovation, no. 2: 97-107, https://www.mitpressjournal s.org/doi/pdf/10.1162 /itgg.2006.1.1.97 accessed 15 $5^{\text {th }}$ of March, 2019

Acs, Z.J., \& Audretsch, D.B. (2003) Handbook of entrepreneurship research: An interdisciplinary survey and introduction. Boston: Kluwer Academic Publishers

Ahmad, N. \& Hoffman, A., OECD (2007) „A Framework for Addressing and Measuring Entrepreneurship. Entrepreneurship Indicators Steering Group", available on-line at: https://www.oecd.org/sdd/business-stats/39629644.pdf, accessed 15 February, 2019, available at SSRN: https://ssrn.com /abstract=2220727 or http://dx.doi.org/10.2139/ssrn.2220727, accessed $15^{\text {th }}$ of February, 2019

Albu, N., Calu, A.D. \& Guse, R. (2016) "The role of accounting internships in preparing students' transition from school to active life", Accounting and Management I nformation Systems vol. 15, no. 1: 131-153 
Amundam, D.N. (2019) "Enhancing potential social innovative thinking, responsible, social entrepreneurship education: A curriculum content and teaching method model", J ournal of Entrepreneurship Education, vol. 22, no. 5: 1-21

Arasti, Z., Falavarjani, M.K. \& Imani pour, N. (2012) "A study of teaching methods in entrepreneurship education for graduates' students", Higher Education Studies, vol. 2, no. 1: 2-10

Atieno, O. P. (2009) "An analysis of the strengths and limitation of qualitative and quantitativeresearch paradigms", Problems of education in the $21^{\text {st }}$ century, vol. 13: 13-18

Avram, B. \& Sabou, S. (2016) „The Influence of Education on the Entrepreneurial behaviour in Romania", Analele Universității din Oradea - Științe Economice, vol. 25, no. 1: 447-457

A wan, N., \& A hmad, N. (2017) „Intentions to become an entrepreneur: survey from University students of Karachi", International Journal of Business, Economics and Law, vol. 13, no. 2

Badulescu, D. (2015) „Entrepreneurial career perception of master students: realistic or rather enthusiastic?", Analele Universității din Oradea - Științe Economice, vol. 24, no. 2: 284-293

Bar-Lev, S., Beimal, D., \& Rechavi, A. (2019) "To be or not to be an entrepreneur? Entrepreneurial tendencies and future orientation among male and female information-systems students", J ournal of Entrepreneurship Education, vol. 22, no. 5: 1-13

Bergmann, H., Geissler, M., Hundt, C., \& Grave, B. (2018) "The climate for entrepreneurship at higher education institutions", Research Policy, vol. 47, no. 4: 700-716

Bertram D. (2016) "Likert Scales" available on-line at: https://docplayer.net/17623968-Likert-scales-are-the-meaning-of-life-danebertram.html, accessed 15 February, 2019

Boh, W.F., DeHaan, U., \& Strom, R. (2016) "University technology transfer through entrepreneurship: faculty and students in spinoffs", The J ournal of Technology Transfer, vol. 41, no 4: 661-669

Botezat, E.A. \& Borza, A.F. (2016) „Exploring Entrepreneurial Potential among Students", Analele Universității din Oradea - Științe Economice, vol. 15, no. 2: 488-496

Burton, M.D., Sorensen, J.B., \& Dobrev, S.D. (2016) „A careers perspective on entrepreneurship", Entrepreneurship: Theory and Practice, vol. 40, no. 2: 237-247

Călin-Costin, G.D. (2013) „The Risk - an element that influences the success of an entrepreneur, " Ovidius University Annals, Economics Sciences Series, vol. 13, no. 1: 732-735

Cantaragiu, R., Păunescu, C. \& Hadad, S. (2014) „The social impact of university entrepreneurship in Romania: Is the institutional discourse replicated or adapted?", Management \& Marketing, vol. 9, no. 4: 403-422 
Casson, M. (1982) The entrepreneur: An economic theory, Totowa, N.J: Barnes \& Noble Books

Ceptureanu, E. G. (2016) "How to enhance entrepreneurship in UniversitiesBucharest University of Economic Studies Case Study", Analele Universității din Oradea - Științe Economice, vol. 25, no. 1: 881-888

Chen, L. W.\& Thompson, P. (2014) „Skill balance and entrepreneurship evidence from online career histories", available on-line at: http://citeseenx.ist.psu.edu /viewdoc/download?doi=10.1.1.1007.9062\&rep=repl\&type=pdf, accessed 15 February, 2019

Cismariu (Zepa), L. (2014) „Entrepreneur or employe in the context of economic crisis?", The Annals of the University of Oradea. Economic Sciences, vol. XXIII, $1^{\text {st }}$ Issue / J uly: 283-291

Cooney, T.M. (2012) Entrepreneur skills for growth-orientated businesses, OECD.

Cooper, A. (2003) "Entrepreneurship: The past, the present, the future”. In Z. J. Acs $\&$ D. B. Audretsch (Eds.), Handbook of entrepreneurship research: An interdisciplinary survey and introduction (pp. 21-34), Boston: Kluwer Academic Publishers

Demsetz, H. (1983) „Theneglect of theentrepreneur", Entrepreneurship, Lexington: Lexington Books, pp: 271-280

Diaconu, M. \& Duțu, A. (2016) "Cross-border collaboration in entrepreneurial education in universities", The USV Annals of Economics and Public Administration, vol. 16, no. 23: 30-36

Eryanto, H. \& Swaramarinda, D.R. (2018) "Influence ability, perception of change and motivation to intention of entrepreneurship: overview of analysis in students of faculty of economics Universitas Negeri Jakarta", J ournal of Entrepreneurship Education, vol. 21, no. 3: 1-10

Fiet, J.O. (2001) "The theoretical side of teaching entrepreneurship", J ournal of Business Venturing, vol. 16, no. 1: 1-24

Filip, P. (2017) „Development of individual entrepreneurship in Poland under crisis conditions", Analele Universității Ovidius Seria Științe Economice, vol. 17, no. 1: 484-490

Fini, R., Meoli, A., Sobrero, M., Ghiselli, S. \& Ferrante, F. (2016) "Student entrepreneurship: demographics, competences and obstacles", Technical Report, DOI: 10.13140/RG.2.1.3126.7602, available on-line at: https://www.researchgate.net/publication/296639413_Student_Entrepreneursh ip_Demographics_Competences_and_Obstacles

Gaglio, C. \& Katz, J. A. (2001) "The psychological basis of opportunity identification: entrepreneurial alertness", Small Business Economics, vol. 16: 95-111

Gaglio, C. M., (1997) „Opportunity identification; review, critique and suggested research directions", Advances in Entrepreneurship, Firm Emergence and Growth, vol. 3: 139-202

Gartner, W. B. (1988) "'Who is an entrepreneur?' Is the wrong question", American J ournal of Small Business, Spring 1988: 11-32 
Ghicajanu, M. (2014) "Innovation and antrepreneurial creativity business during Henry Ford”, Annals of the „Constantin Brâncuşi” University of Târgu Jiu, Economy Series, vol. 2, $1^{\text {st }}$ issue 84-88

Hambrick, D. C. (2007) „The field of management's devotion to theory: Too much of a good thing?", Academy of Management J ournal, no. 50: 1346-1352

Hebert, R. F., \& Link, A. N. (1989) "In search of the meaning of entrepreneurship", Small Business Economics, vol. 1, no. 1: 39-49

Heider, F. (1958) The psychology of interpersonal relations, New Y ork: Wiley

Hmieleski, K. M. \& Baron R. A. (2009) „Entrepreneurs' optimism and new venture performance: a social cognitive perspective", Academy of Management J ournal, vol. 52, no. 3: 473-488

Hsieh, C., Parker, S.C. \& van Praag, M.C. (2016) „Risk, balanced skills and entrepreneurship, Small Business Economy", Available on-line at: https://research-api .cbs.dk/ws/portal files/portal/45533353/Hsieh_Parker_van Praag_Risk_Balanced_Skills_and_Entrepreneurship.pdf, $\quad$ accessed ${ }^{-} \overline{15}$ February, 2019

Iazzolino, G., Coniglio, I.M., Verteramo, S., \& Giglio, C. (2019) “University students and entrepreneurship: An empirical analysis on Italian Universities", J ournal of EntrepreneurshipEducation, vol. 22, no. 5: 1-16

Imbrișcă, C.I. \& Neatu, A.M. (2015) „Entrepreneurship in Romania A behavioral economics perspective", The Annals of the University of Oradea Economic Sciences, vol. 24, $1^{\text {st }}$ issue: 95-105

Isac, C. (2017) „Therole of training companies in entrepreneurial education”, Annals of the Constantin Brâncuşi University of Târgu Jiu, Economy Series, no. 1: $126-130$

Kelley, D.J., Bosma, N., Amorós, J.E., \& Global Entrepreneurship Research Association (GERA) (2010) Global Entrepreneurship Monitor 2010 Global report Report, Universidad del Desarrollo, CL

Kirzner, I. M. (2009) "The alert and creative entrepreneur", Small Business Economics, vol. 32, no. 2: 145-152

Kuip, I. \& Verheul, I. (2003) "Early development of entrepreneurial qualities: The role of initial education", SCALES-paper N200311. EIM Business \& Policy Research, Zoetermeer

Kumar, S., Vifenda, A. T. \& Brigitta, M. (2013) „Students' willingness to become an entrepreneur: a survey of non-business students of President University", IOSR J ournal of Business and Management vol. 15, no. 2: 94-102

Lazear, E. P. (2004) „Bal anced skills and entrepreneurshi p”, Papers and Proceedings of the One Hundred Sixteenth Annual Meeting of the American Economic Association San Diego, The American Economic Review, vol. 94, no. 2: 208-211

Likert, R. (1932) „A technique for the measurement of attitudes", Archives of Psychology, vol. 22, no. 140: 5-55 
Lin, F., Moriano, J.A. \& Zarnowska, A. (2008) Teaching psychology of entrepreneurshi p: Perspective fromsix European, $1^{\text {st }} \mathrm{Ed}$ : Impreso en Espana

Marin, E., Horobet, A. \& Belascu, L. (2015) “Master students' perception on the correlation between academic curricula and labor market requirements - a comparative analysis of master programs in economics from Bucharest and Sibiu", The USV Annals of Economics and Public Administration, Vol. 15, Issue 1(21): 264-269

Martin, A., Carree, A. \& Thurik, R. (2010) The Impact of Entrepreneurship on Economic Growth, Part of the International Handbook Series on Entrepreneurship book series, vol. 5

Medar, L. I. (2015) „Entrepreneurship education and the economy vicious circles", Annals of the Constantin Brâncuşi University of Târgu Jiu, Economy Series, no. 1: 33-36

Medinschi, S. (2014) "Employee's attitude versus entrepreneur's attitude", Annals. Economic Science Series. Timisoara, vol. 20: 202-209

Minica, M. (2017) "A pproach of the manager - leader - entrepreneur relation from the viewpoint of applied microeconomics", Analele Universitatii Eftimie Murgu, Resita, Fascicola II, Studii economice: 162-171

Moberg, K. S., Vestergaard, L., J orgensen, C., Markussen, E., \& Sose, H. (2013) "How to assess the development of entrepreneurship education at university level - the case of Denmark", Handbook of Entrepreneurship Education Series: The Entrepreneurial University, Fayolle, A. \& Redford, D. (eds.), Edward Elgar Publishing Limited, no.4

Moberg, K., Vestergaard, L., Fayolle, A., Redford, D., Cooney, T., Singer, S., Sailer, K. \& Filip, D. (2014) "How to assess and evaluate the influence of entrepreneurship education: A report of the ASTEE project with a user guideto the tools", The ASTEE project - Assessment Tools and Indicators for Entrepreneurship Education" available on-line at: http://ntsnet.dk/ sites/default/files/ASTEE\%20rapport\%20juni\%202014.pdf, accessed 15 February, 2019

Munteanu, V. (2015) "Social entrepreneur and skills profile", Ovidius University Annals, Economics Sciences Series, vol. 15, no. 1: 556-559

Negoescu, G. \& Negoescu, L.G. (2013) „The entrepreneurship, an actual challenge for the young graduates of higher education institutions", Analele Universității Ovidius Seria Stiiințe Economice, vol. 13, no. 1: 573-578

Nicodim, L., Croitoru, G., \& Duica, M. (2016) "Quantitative investigation on the influence of social customer relationship management on the profitability of companies", "Ovidius" University Annals, Economic Sciences Series, vol. 16, $2^{\text {nd }}$ issue: 367-371

Nikoloski, D., Angeleski, M., Rocheska, S.\& Mancheski, G. (2014) „Does thehigher education promote students' entrepreneurial potential in the South-Eastern European countries?", Annals of the Constantin Brâncuşi University of Târgu J iu, Economy Series, no. 2: 6-12 
Oosterbeek, H., Praag, v. M., \& Ijsselstein, A. (2010) „The impact of entrepreneurshi peducation on entrepreneurship skill and motivation, Elsevier, vol. 54, no. 3: 442-454

Ozaralli, N., \& Rivenburgh, N. K. (2016) „Entrepreneurial intention: antecedents to entrepreneurial behavior in the USA and Turkey", Journal of Global Entrepreneurship Research, vol. 6, no. 3:1-32

Pavlov, D. (2014) "Academic production of entrepreneurs \pm myth or reality?", Analele Universității Eftimie Murgu, Seria Studii Economice, vol. 2: 256-271

Peng, Z., Lu, G., \& Kang, H. (2012) „Entrepreneurial intentions and its influencing factors: A survey of the university students in Xi'an China", Creative Education, vol. 3. no. 8: 95-100

Peterson, K.D., Wahlquist, C., \& Bone, K. (2000) "Student surveys for school teacher evaluation", J ournal of Personnel Evaluation in Education, vol. 14(2): 135-153 DOI:10.1023/A:1008102519702

Pitulice C.I \& Manea, C.L. (2015) "Accounting education and its place in the Romanian economic education literature", Accounting and Management Information Systems, vol. 14, no. 1: 36-59

Ploae, C. (2014) "The influence of business simulation on students entrepreneurship", Analele Universității Ovidius Seria Științe Economice, vol. 14, no. 1: $57-64$

Pribeanu, G. \& Milutin, I. M. (2014) „The entrepreneurship and the students practice", Lucrări Științifice Management Agricol, vol. 16, no. 2: 127-130

Rasmussen, E., \& Borch, O.J. (2010) "University capabilities in facilitating entrepreneurship: A longitudinal study of spin-off ventures at mid-range universities", Research Policy, vol. 39, no. 5: 602-612

Rasmussen, E., Bulanova, O., Jensen, A. \& Causen, T. (2012) Theimpact of sciencebased entrepreneurial firms: A literature review and policy synthesis, Norway: Nordlands Forskning-Nordl and Research Institute

Roșca, R. \& Șipoș-Gug, S. (2015) "The role of student-centered education in stimulating the entrepreneurial spirit of university graduates", Analele Universității din Oradea - Științe Economice, vol. 24, no. 1: 555-567

Roșca, R.\&Șipoș-Gug, S. (2015) „The university as a generator of entrepreneurial education", Analele Universității Ovidius Seria Științe Economice, vol. 15, no. 1: $605-610$

Schulte, P. (2014) „Entrepreneurial university”, Analele Universității Eftimie Murgu, Seria Studii Economice, vol 2: 330-340

Schumpeter, J. A. (1934) The theory of economic development, Cambridge, MA: Harvard Economic Studies

Scott, M.G., \& Twomey, D.F. (1988) "The long-term supply of entrepreneurs: students' career aspirations in relation to entrepreneurship", J ournal of Small Business Management, vol. 26, no. 4: 5-13

Shane, S. (2002) The foundations of entrepreneurship (Vol. I \& II), Cheltenham: Edward Elgar. 
Shane, S., \& Venkataraman, S. (2000) "The promise of entrepreneurship as a field of research", Academy of Management Review, vol. 25, no. 1: 217-226

Stanciu, V. \& Tinca, A. (2017) "Solid Knowledge Management - The ingredient companies need for performance: A Romanian insight", Accounting and Management Information Systems vol. 15, no. 1: 131-153

Sumedrea, S. (2017) „Fostering entrepreneurial culture in university”, Bulletin of the Transilvania University of Braşov Series Economic Sciences, vol. 10, no. 1: 111-118

Tang, J., (Micki) Kacmar, K. M.\& Busenitz, L. (2012) „Entrepreneurial alertness in the pursuit of new opportunities", J ournal of Business Venturing, no. 27: 77-94

Tecău, A. S. (2016) "The role of international internships conducted during academic studies in development of entrepreneurial skills", Bulletin of the Transilvania University of Braşov Series Economic Sciences, vol. 9, no. 1: 169176

Thurik, R. \& Wennekers, S. (2004) „Entrepreneurship, small business and economic growth", J ournal of Small Business and Enterprise Development, vol. 11, no.1:140-149, available on-line at: https://doi.org/10.1108/1462 6000410519173

Toktamysov, S.Z., Vekilova, A.I., Gasimzade, E.E., Kurilova, A.A., \& Mukhin, K.Y. (2019) "Implementing the education of future entrepreneurs in developing countries: Agile integration of traditions and innovations", J ournal of Entrepreneurship Education, vol. 22, no. 5: 1-13

Tsakiridou, H. \& Stergiou, K. (2014) „Entrepreneurial competences and entrepreneurial intentions of students in primary education", International J ournal of Humanities Social Sciences and Education (IJHSSE) vol. 1, no. 9:106-117

van der Scheer, E.A., Bijlsma, H. J. E. \& Glas, C. A. W. (2018) "Validity and reliability of student perceptions of teaching quality in primary education", School Effectiveness and School Improvement, vol. 30, no. 1: 30-50

Venkataraman, S. (1994) "Associate editor's note", J ournal of Business Venturing, vol. 9, no. 1: 3-6

Venkataraman, S. (1997) "The distinctive domain of entrepreneurship research", In J. Katz (ed.), Advances in entrepreneurship, firmemergence and growth, vol. 3: 119-138. Greenwich, CT: JAI Press

Wang, C.K., \& Wong, P.K. (2004) "Entrepreneurial interest of university students in Singapore", Technovation, vol. 24, no. 2: 163-172

Wright, M., Piva, E., Mosey, S., \& Lockett, A. (2009) "Academic entrepreneurship and business schools", The J ournal of Technology Transfer, vol. 34, no. 6: 560-587

Zamcu, E. (2013) „Study about students' entrepreneurship spirit”, The USV Annals of Economics and Public Administration, vol. 13, no 18: pp. 102-107

Zoltan, A. (2006) "How is entrepreneurship good for economic growth?", Innovations: Technology, Governance, Globalization, vol. 1, no. 1: pp. 97-107 
*** European Commission (2006), Proposal for a Council Recommendation on Key Competences for Lifelong Learning, available on-line at: https://eurlex.europa eu/legal-content/EN/TXT/PDF/?uri=CELEX:52018SC0014\& from=EN, accessed $15^{\text {th }}$ of February, 2019

*** European Commission (2018) "Communication from the Commission to the European Parliament, The Council, The European Economic and Social Committee and the Committee of the Regions Horizon 2020 interimeval uation: maximising the impact of EU research and innovation", available online at: https://ec.europa.eu/transparency/regdoc/rep/1/2018/EN/COM-2018-2-F1-ENMAIN-PART-1.PDF, accessed 24 ${ }^{\text {th }}$ of March, 2019.

*** European Commission, „Promoting entrepreneurship”, available on-line at: https://ec.europa.eu/growth/smes/promoting-entrepreneurship_It, accessed $15^{\text {th }}$ of February, 2019

*** European Commission, Education and culture DG (2006) "Key competencies for lifelong learning, European Reference Framework", available at: http://ec.europa.eu/dgs/education_culture/publ/pdf/II-learning/keycomp_ en.pdf, accessed 15 $15^{\text {th }}$ of February, 2019

*** European Social Entrepreneurship and Innovative Studies Institute, „Practice Guarantees Successful Career", available on-line at: http://europe institutecom/practice-guarantees-successful-career/, accessed $15^{\text {th }}$ of February, 2019

*** Komarkova, I., Conrads, J., Collado A., (2015) “Entrepreneurship Competence: an overview of existing concepts, policies and initiatives: in-depth case studies report", publication Office of the European Union - Joint Research Centre, Institute for Prospective Technological Studies, EUR 27423 EN, doi:10.2791/951054, available on-line at: https://ec.europa.eu/jrc/er/ publication/entrepreneurship-competence-overview-existing-conceptspolicies-and-initiatives-final-report, accessed 24 March, 2019

*** OECD (2014) "J ob creation and local economic development", available on line at: http://www.oecd.org/cfe/leed/job-creation-and-local-economicdevel opment-9789264215009-en.htm, accessed 15 th of February, 2019

*** Voyage (2015) Survey on youth's comprehension about entrepreneurship, available online at http://europe-institute.com/wp-content/uploads/Survey-onyouth\%E2\%80\%99s-comprehension-about-entrepreneurshi p.pdf, accessed $24^{\text {th }}$ of March 2019 